\title{
PENERAPAN MODEL PROBLEM BASED LEARNING UNTUK MENINGKATKAN KREATIVITAS DAN HASIL BELAJAR MATEMATIKA SISWA DI KELAS VIII SMP NEGERI 4 BARUMUN
}

Oleh :

\author{
Eka Retno Wulandari ${ }^{1)}$, Nova Christina Dewi ${ }^{2)}$, Haritsah Hammamah Harahap ${ }^{3)}$ \\ Fakultas Keguruan dan Ilmu Pendidikan, Universitas Graha Nusantara Padangsidimpuan
}

\begin{abstract}
Abstrak
Penelitian ini bertujuan antara lain: pertama, mengetahui apakah penerapan Model Problem Based Learning dapat meningkatkan kreativitas dan hasil belajar matematika siswa pada materi pokok persamaan garis lurus di kelas VIII SMP Negeri 4 Barumun. Kedua, mendeskripsikan penerapan Model Problem Based Learning dapat meningkatkan kreativitas dan hasil belajar matematika siswa pada materi pokok persamaan garis lurus di kelas VIII SMP Negeri 4 Barumun. Jenis penelitian ini adalah Penelitian Tindak Kelas (PTK) yang terdiri dari 2 siklus. Subjek penelitian ini adalah kelas VIII-1 yang berjumlah 26 siswa. Hasil penelitian menunjukkan bahwa kreativitas dan hasil belajar matematika siswa dengan menerapkan Model Problem Based Learning pada siklus I diperoleh dengan kategori minimal cukup yaitu sebesar 46,1\% dan pada siklus II meningkat menjadi 88,5\%. Peningkatan dari siklus I ke siklus II sebesar 42,4\%. Dengan indikator pencapaian telah tercapai $\geq 80 \%$. Kemudian untuk hasil observasi aktivitas siswa pada siklus I diperoleh kadar aktivitas siswa sebesar 75,08\% “Cukup” pada siklus II 87,27\% "Baik”. Peningkatan yang terjadi dari siklus I ke siklus II sebesar 12,19\%. Indikator pencapaian telah tercapai $\geq$ $80 \%$. Sedangkan untuk hasil observasi kemampuan guru pada siklus I dan siklus II diperoleh dengan kategori "Baik".
\end{abstract}

Kata kunci: Model Problem Based Learning, Kreativitas Matematika Siswa

\section{PENDAHULUAN}

Pendidikan memiliki peranan yang sangat penting untuk menentukan tinggi rendahnya sumber daya manusia dalam suatu negara. Hamdani (2011:21) menyatakan pendidikan adalah sebuah sistem terencana untuk mewujudkan suasana belajar dan proses pembelajaran atau pelatihan agar peserta didik dapat mengembangkan potensi dirinya secara akif sehingga memiliki kekuatan spiritual keagamaan, emosional, pengendalian diri, kepribadian, kecerdasan akhlak mulia, serta keterampilan yang diperlukan dirinya dan masyarakat. Pendidikan yang baik dapat meningkatkan kualitas sumber daya manusia. Semakin baik penyelenggaraan proses pendidikan maka semakin tinggi kualitas sumber daya yang dihasilkan.

Matematika merupakan salah satu mata pelajaran yang menduduki peranan penting dalam pendidikan, hal ini dapat dilihat dari alokasi waktu mata pelajaran matematika di sekolah lebih banyak dibandingkan mata pelajaran lain. Mata pelajaran Matematika perlu diberikan untuk membekali peserta didik dengan kemampuan berpikir logis, analitis, sistematis, kritis, kreatif, serta kemampuan bekerjasama. Kompetensi tersebut diperlukan agar peserta didik dapat memiliki kemampuan memperoleh, mengelola, dan memanfaatkan informasi untuk bertahan hidup pada keadaan yang selalu berubah, tidak pasti, dan kompetitif.

Hasil belajar merupakan tolak ukur untuk mengetahui tercapainya tujuan pembelajaran matematika. Menurut Jihad (2013:15) hasil belajar adalah perubahan tingkah laku siswa secara nyata setelah dilakukan proses belajar mengajar yang sesuai dengan tujuan pengajaran. Selain itu, menurut Rusmono (2012:10) menyatakan hasil belajar adalah perubahan perilaku individu yang meliputi ranah kognitif, afektif, dan psikomorik. Perubahan itu diupayakan untuk mencapai tujuan proses pembelajaran. Dengan demikian hasil belajar matematika merupakan perubahan perilaku siswa dalam segala aspek pembelajaran matematika setelah proses pembelajaran. Selain dari hasil belajar, tolak ukur keberhasilan pembelajaran juga dapat dilihat dari kreativitas siswa dalam menyelesaikan permasalahan matematika.

Pada kenyataannya hasil belajar matematika belum sesuai harapan yaitu tercapainya tujuan pembelajaran sehingga terselesaikannya permasalahan matematika. Hal ini terbukti dengan peneliti melakukan wawancara dengan salah seorang guru matematika di SMP Negeri 4 Barumun, yaitu Bapak Indra Syahlan Ritonga yang mengajar di kelas VIII, menyatakan bahwa salah satu kelemahan yang dialami 
ISSN. 2621-9832

JURNAL MathEdu (Mathematic Education Journal) http://journal.ipts.ac.id/index.php/MathEdu Vol. 4 . No. 3 Mounth 2021

siswa adalah kurangnya kemampuan kreativitas matematika siswa dalam belajar matematika sehingga menyebabkan hasil belajar matematika siswa masih tergolong rendah. Salah satu materi yang sulit dirasakan oleh siswa adalah pokok bahasan persamaan garis lurus. Siswa sangat sulit menyelesaikan soalsoal dalam bentuk essay test atau dalam bentuk soal cerita, dan siswa sulit sekali menghubungkannya dalam kehidupan sehari-hari. Selain wawancara, peneliti juga melakukan observasi dengan memberikan tes awal di kelas VIII SMP Negeri 4 Barumun. Dari hasil observasi yang peneliti lakukan di kelas VIII SMP Negeri 4 Barumun, diketahui bahwa metode pembelajaran yang dilaksanakan dalam proses belajar mengajar di kelas adalah model pembelajaran langsung seperti metode ceramah. Selama proses belajar mengajar berlangsung ada siswa yang tidak memperhatikan penjelasan dari guru, dan ada sebagian siswa yang tidak membawa buku panduan. Pada saat guru memberi pertanyaan, siswa tidak mau menjawab jika tidak ditunjuk, dan siswa tidak ada yang bertanya apabila ada materi yang belum jelas.

Untuk meningkatkan hasil belajar dan kreativitas siswa dipengaruhi oleh beberapa faktor salah satunya adalah penggunaan model pembelajaran matematika. Dalam pemecahan masalah matematika, diperlukan pemikiran dan gagasan yang kreatif dalam membuat (merumuskan) dan menyelesaikan model matematika serta menafsirkan solusi dari suatu masalah matematika. Pemikiran dan gagasan yang kreatif tersebut akan muncul dan berkembang jika proses pembelajaran matematika di dalam kelas menggunakan model pembelajaran yang tepat.

\section{Krativitas Matematika Siswa}

Menurut Guilford (dalam Munandar, 2009) menyatakan bahwa: "Kreativitas menyangkut pada cara berpikir konvergen dan divergen. Cara berpikir konvergen adalah cara-cara individu dalam memikirkan sesuatu dengan berpandangan bahwa hanya ada satu jawaban yang benar. Sedangkan cara berpikir divergen adalah kemampuan individu untuk mencari berbagai alternatif jawaban terhadap suatu permasalahan. Dalam kaitannya dengan kreativitas, orang yang kreatif lebih banyak memiliki cara-cara berpikir divergen daripada cara-cara berpikir konvergen sehingga kemampuan berpikir divergen merupakan indikator dari kreativitas." Kreativitas merupakan hal yang sulit untuk diukur, Westen (Satiadarma: 2003) menjelaskan bahwa salah satu cara untuk mengevaluasi kreativitas seseorang adalah dengan mengukur kemampuan berfikir divergen. Artinya seberapa banyak seseorang mampu menemukan kemungkinan-kemungkinan jalan pemecahan terhadap situasi tertentu. Peneliti akan meneliti kreativitas siswa dengan mengukur kemampuan divergennya. Santrok (2014) menyatakan bahwa pemikiran divergen (berpikir kreatif) merupakan salah satu ciri dari kreativitas. Haylock (1997) menjelaskan dua pendekatan utama untuk mengenal pemikiran (berpikir) divergen dalam matematika yaitu: 1) Memperlihatkan respon-respon subjek untuk memecahkan masalah, dimana suatu proses kognitif khusus, yaitu memahami karakteristik khusus, yaitu memahami karakteristik berpikir kreatif yang diharapkan berhasil. Caranya dengan mengatasi ketetapan da berpikir diluar kebiasaan. 2) Menetukan kriteria dari suatu produk yang merupakan indikator berpikir divergen. Caranya dengan melihat produksi divergen yang meliputi fleksibility, keaslian, dan kelayakan (appropriatness). Guildford (Satiadarma: 2003) menyatakan bahwa karakteristik pemikiran kreatif berkaitan dengan lima ciri yang menjadi sifat kemampuan berpikir yaitu: kelancaran (fluency), keluwesan (flexibility), keaslian (originality), penguraian (elaboration), dan perumusan kembali (redefinition).

Berdasarkan uraian diatas, maka dapat dikemukakan bahwa kreativitas matematika adalah kemampuan siswa untuk melihat dan menemukan ide-ide baru atau hal-hal yang luar biasa di dalam menyelesaikan masalah matematika yang merujuk kepada keluwesan, kefasihan, keaslian dan penguraian.

\section{Model Problem Based Learning}

Menurut Glazer (2001), mengemukakan bahwa: "Problem Based Learning merupakan suatu strategi pembelajaran dimana siswa secara aktif dihadapkan pada masalah kompleks dalam situasi yang nyata". Sedangkan menurut Arends (dalam Trianto, 2010) mengemukakan bahwa: "Problem Based Learning merupakan suatu pembelajaran di mana siswa mengerjakan permasalahan dengan maksud untuk menyusun pengetahuan mereka sendiri, mengembangkan keterampilan berpikir dan keterampilan pemecahan masalah, mengembangkan kemandirian dan percaya diri". Selanjutnya, Dewey (dalam Trianto, 2010) yang menyatakan bahwa: "Problem Based Learning adalah interaksi antara stimulus dengan respon, merupakan hubungan dua arah antara belajar dan lingkungan. Lingkungan memberi masukan kepada siswa berupa bantuan dan masalah. Sedangkan sistem saraf otak berfungsi menafsirkan bantuan itu secara efektif sehingga masalah yang dihadapi dapat diselidiki, dinilai, dianalisis, serta dicari pemecahannya dengan baik". Model Problem Based Learning bercirikan penggunaan masalah kehidupan nyata sebagai suatu yang harus dipelajari siswa. Dengan model Problem Based Learning diharapkan siswa mendapatkan lebih banyak kecakapan daripada pengetahuan yang dihafal. Mulai dari kecakapan memecahkan masalah, 
kecapakan berpikir kritis, kecakapan berpikir kreatif, kecakapan bekerja dalam kelompok, kecakapan interpersonal dan komunikasi, serta kecakapan pencarian dan pengolahan informasi (Amir,2007).

Sehingga dapat disimpulkan, bahwa dalam Problem Based Learning pembelajarannya lebih mengutamakan proses belajar, dimana tugsa guru harus memfokuskan diri untuk membantu siswa, mencapai keerampilan mengarahkan diri. Guru dalam model ini berperan sebagai penyaji masalah, penanya, mengadakan dialog, membantu menemukan masalah, dan pemberi fasilitas pembelajaran. Selain itu guru memberikan dukungan yang dapat meningkatkan pertumbuhan inkuiri dan intelektual siswa. Model ini hanya dapat terjadi jika guru dapat menciptakan lingkungan kelas yang terbuka dan membimbing pertukaran gagasan.

Menurut Trianto (2007) Pelaksanaan Model Problem Based Learning terdiri dari 5 tahap proses yaitu:

Tahap pertama, adalah proses orientasi peserta didik pada masalah. Pada tahap ini guru menjelaskan tujuan pembelajaran, menjelaskan logistic yang diperlukan, memotivasi peserta didik untuk terlibat dalam aktivitas pemecahan masalah dan pengajuan masalah. Tahap kedua, mengorganisasi peserta didik. Pada tahap ini guru membagi peserta didik kedalam kelompok, membantu peserta didik mendefenisikan dan mengorganisasikan tugas belajar yang berhubungan dengan masalah. Tahap ketiga, membimbing penyelidikan individu maupun kelompok. Pada tahap ini guru mendorong peserta didik untuk mengumpulkan informasi yang dibutuhkan, melaksanakan eksperimen dan penyelidikan untuk mendapatkan penjelasan dan pemecaham masalah. Tahap keempat, mengembangkan dan menyajikan hasil. Pada tahap ini guru membantu peserta didik dan merencakan dan menyiapkan laporan, dokumentasi, dokumen, atau model, dan membantu mereka berbagi tugas dengan sesame temannya. Tahap kelima, menganalisis dan mengevaluasi proses dan hasil pemecaham masalah. Pada tahap ini guru membantu peserta didik untuk melakukan refleksi atau evaluasi terhadap proses dan hasil pemyelidikan yang mereka lakukan

\section{METODE PENELITIAN}

Penelitian ini dilaksanakan di SMP Negeri 4 Barumun. Waktu penelitian adala semester ganjil tahun pelajaran 2020/2021. Subjek dalam penelitian ini adalah siswa kelas VIII-1 SMP Negeri 4 Barumun yang berjumlah 26 siswa. Teknik pengumpulan data dalam penelitian ini adalah: 1) Tes digunakan untuk mengumpulkan data yang sifatnya mengevaluasi hasil belajar, 2) Observasi digunakan untuk mengumpulkan data tentang aktivitas pembelajaran, 3) Dokumentasi. Sedangkan instrument penelitian ini adalah: RPP, lembar tes kreativitas matematika siswa, lembar observasi.

Sebelum melakukan penelitian, tindakan awal yang dilakukan peneliti adalah melakukan wawancara dengan salah satu guru mata pelajaran matematika di kelas VIII SMP Negeri 4 Barumun yaitu Bapak Indra Syahlan Ritonga untuk mengetahui permasalahan siswa dalam mengikuti pembelajaran matematika. Kemudian peneliti melakukan tindakan observasi dengan memberikan soal pretest untuk mengetahui bagaimana kemampuan kreativitas siswa dengan melihat hasil pengerjaan pretest tersebut.

Jenis penelitian ini adalah Penelitian Tindakan Kelas yang bertujuan untuk mengetahui apakah penerapan Model Problem Based Learning dapat meningkatkan kreativitas dan hasil belajar siswa. Sesuai dengan jenis penelitian ini yaitu penelitian tindakan kelas, maka penelitian ini memiliki beberapa tahap yang merupakan suatu siklus. Tiap siklus dilaksanakan sesuai dengan perubahan yang akan dicapai. Pada penelitian ini, suatu siklus tidak dilanjutkan ke siklus berikutnya apabila (1) terdapat $\geq 85 \%$ siswa yang mengikuti tes kreativitas memiliki tingkat kreativitas pada tingkat kemampuan minimal sedang dan (2) dipenuhi paling sedikit dua syarat yang didasarkan pada kriteria peningkatan kreativitas. Penelitian ini meliputi 4 tahap, yaitu perencanaan tindakan, pelaksanaan tindakan, observasi, dan refleksi.

Secara lebih rinci, prosedur pelaksanaan penelitian tindakan kelas menurut Arikunto (2009) adalah sebagai berikut: 
SIKLUS I

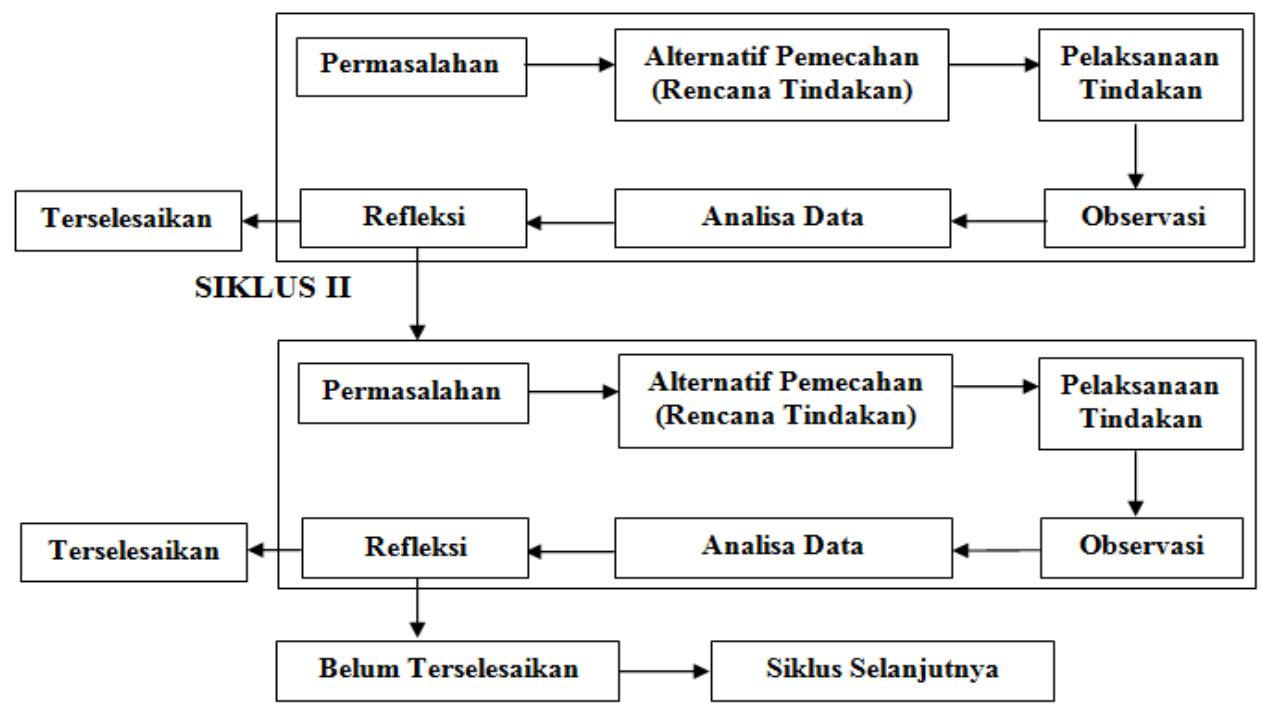

Gambar 1 Prosedur Pelaksanaan Penelitian Tindakan Kelas

\section{HASIL DAN PEMBAHASAN}

Materi yang diajarkan dalam penelitian ini pada siklus I adalah persamaan garis lurus yang meliputi Sistem Koordinat Kartesius dan Gradien Suatu Garis Lurus.

Adapun pelaksanaan penelitian disesuaikan dengan langkah-langkap pembelajaran dengan menggunakan Model Problem Based Learning. Pada siklus I peneliti melakukan perencanaan pembelajaran yaitu: 1) membuat RPP yang sesuai dengan materi yang akan diajarkan, 2) mempersiapkan soal tes dan lembar observasi

Hasil pada siklus I menunjukkan bahwa siswa masih sulit meningkatkan kreativitas matematika pada materi persamaan garis lurus. Hal ini diketahui dari hasil tes yang diberikan kepada siswa dan observasi aktivitas siswa. Dari 26 siswa diperoleh 3 orang siswa dengan persentase 11,5\% dengan kriteria "baik", 9 orang siswa dengan persentase $34,6 \%$ dengan kriteria "cukup", 14 orang siswa dengan persentase $53,8 \%$ dengan kriteria "sangat kurang". Secara klasikal hasil tes kemampuan berpikir kreatif siswa yang memperoleh minimal "cukup" atau 46,1\% dari 26 siswa yang mengikuti tes". Hal ini menunjukkan belum memenuhi kriteria yang ditentukan $\geq 80 \%$. Begitu juga dengan hasil pengamatan observer terhadap aktivitas siswa dalam pembelajaran dilaksanakan setiap kali pertemuan dimana pada siklus I persentase yang di dapat $75,08 \%$ hal ini menunjukkan aktivitas siswa masih pasif dalam pembelajaran. Dari setiap aspek yang diamati yang dinilai masih banyak yang belum mencapai rerata $\geq 80 \%$. Sedangkan hasil observasi kemampuan guru dalam mengelola pembelajaran sudah kategori baik. Berdasarkan hasil ini maka peneliti bersama kolabolator akan mengadakan refleksi untuk perbaikan pada siklus berikutnya untuk meningkatkan kreativitas matematika s siswa. Setelah dilakukan refleksi, maka peneliti melakukan siklus II ternyata hasil tes dan observasi mengalami peningkatan.

Peningkatan kemampuan berpikir kreatif matematika siswa dilihat berdasarkan hasil tes belajar siswa pada siklus I terdapat 12 orang siswa dengan persentase penilaian $46,1 \%$ dari 26 siswa pada kategori "Cukup", pada siklus II terdapat 23 orang siswa dengan persentase penilaian 88,5\% dari 26 siswa dengan kategori "Baik". Jadi dengan penerapan Model Problem Based Learning dapat meningkatkan kemampuan berpikir kreatif matematika siswa pada materi persamaan garis lurus. Untuk hasil yang lebih jelas mengenai peningkatan kemampuan berpikir kreatif matematika siswa dari siklus I ke siklus II dapat dicermati grafik di bawah ini yang menggambarkan peningkatan kemampuan berpikir kreatif siswa dari siklus I ke siklus II sebagai berikut: 


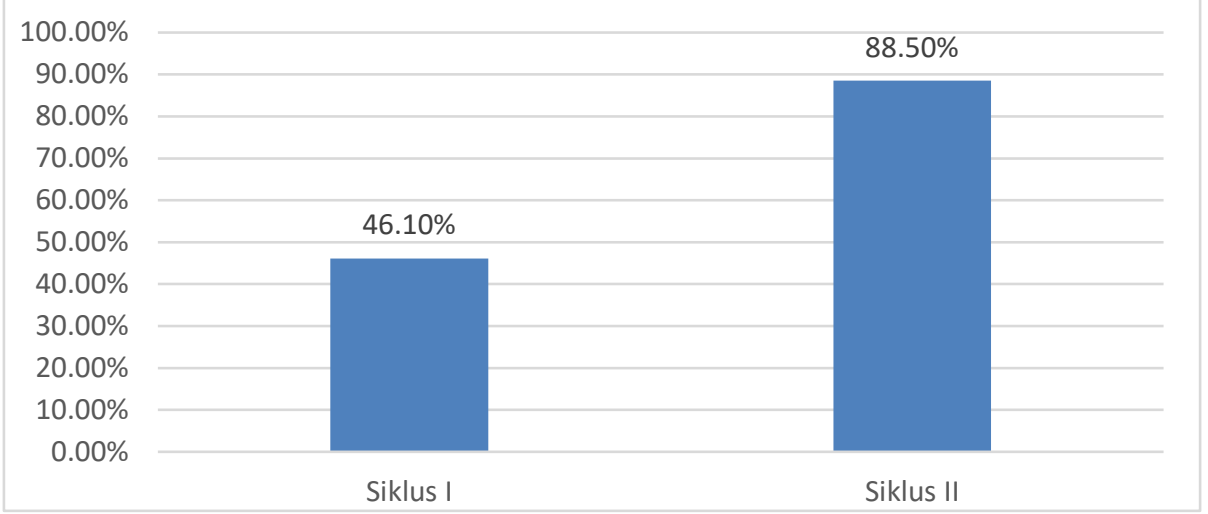

\section{Gambar 1 Peningkatan Kemampuan Berpikir Kreatif Siswa dari Siklus I ke Siklus II}

Gambar di atas menunjukkan bahwa dengan Model Problem Based Learning dapat meningkatkan kemampuan berpikir kreatif siswa pada materi persamaan garis lurus di kelas VIII-1 SMP Negeri 4 Barumun sebesar $\geq 80 \%$.

Bila ditinjau dari segi aktivitas siswa pada siklus I yang tidak memenuhi kriteria yang ditentukan, dimana aktivitas siswa pada siklus I hanya 75,08\% dengan kategori 'cukup'. Sedangkan pada siklus II meningkat menjadi 87,27\% dengan kategori "baik".

Aktivitas siswa ini meningkat baik disebabkan kerjasama yang baik siswa dan guru atau siswa itu sendiri. Jadi didalam proses pembelajaran terjadi interaksi antara guru dan siswa atau siswa itu sendiri. Hal ini mengakibatkan suasana kelas menjadi kondusif, dimana masing-masing siswa dapat melibatkan kemampuannya semaksimal mungkin. Aktivitas yang timbul dari siswa akan mengakibatkan terbentuknya pengetahuan dan keterampilan yang akan mengarah pada peningkatan prestasi. Untuk hasil yang lebih jelas mengenai peningkatan kadar aktivitas siswa dari siklus I ke siklus II dapat dicermati grafik di bawah ini yang menggambarkan peningkatan kadar aktivitas siswa dari siklus I ke siklus II sebagai berikut:

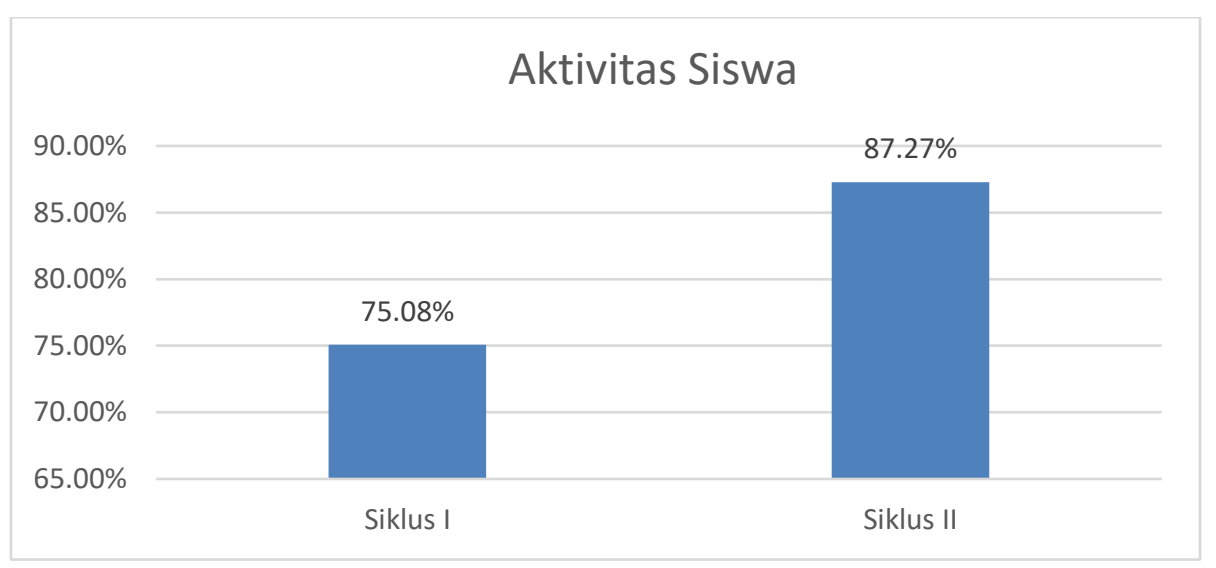

\section{Gambar 2 Peningkatan Kadar Aktivitas Siswa Dari Siklus I ke Siklus II}

Gambar di atas menunjukkan bahwa siswa kelas VIII-1 SMP Negeri 4 Barumun aktif dalam proses pembelajaran dengan model Problem Based Learning pada materi pokok persamaan garis lurus, hal ini terbukti dengan perolehan kadar aktivitas sebesar 87,27\% yang berarti kadar aktivitas siswa dalam proses pembelajaran berada pada kategori baik.

Hasil observasi aktivitas guru yang dilakukan menunjukkan bahwa pelaksanaan dengan Model Problem Based Learning pada pokok bahasan Persamaan garis lurus dalam penelitian ini berjalan dengan baik dan mengalami peningkatan selama pelaksanaan pembelajaran dengan model Problem Based Learning. Dengan demikian Model Problem Based Learning dapat dipertimbangkan untuk meningkatkan mutu pembelajaran.

Berdasarkan hasil observasi kemampuan guru mengelola pembelajaran, pada siklus II berada pada kategori "baik". Hal ini dapat dilihat dari pengamatan observer dari siklus I. dapat disimpulkan dari hasil 
JURNAL MathEdu (Mathematic Education Journal) http://journal.ipts.ac.id/index.php/MathEdu Vol. 4 . No. 3 Mounth 2021

penelitian, kemampuan guru mengelola pembelajaran sudah baik atau guru telah mampu menerapkan metode pembelajaran tersebut sehingga dapat meningkatkan kemampuan belajar matematika siswa. Untuk hasil yang lebih jelas mengenai peningkatan kadar aktivitas guru dalam mengelola pembelajaran dari siklus I ke siklus II dapat dicermati grafik di bawah ini yang menggambarkan peningkatan kadar aktivitas guru dari siklus I ke siklus II sebagai berikut:

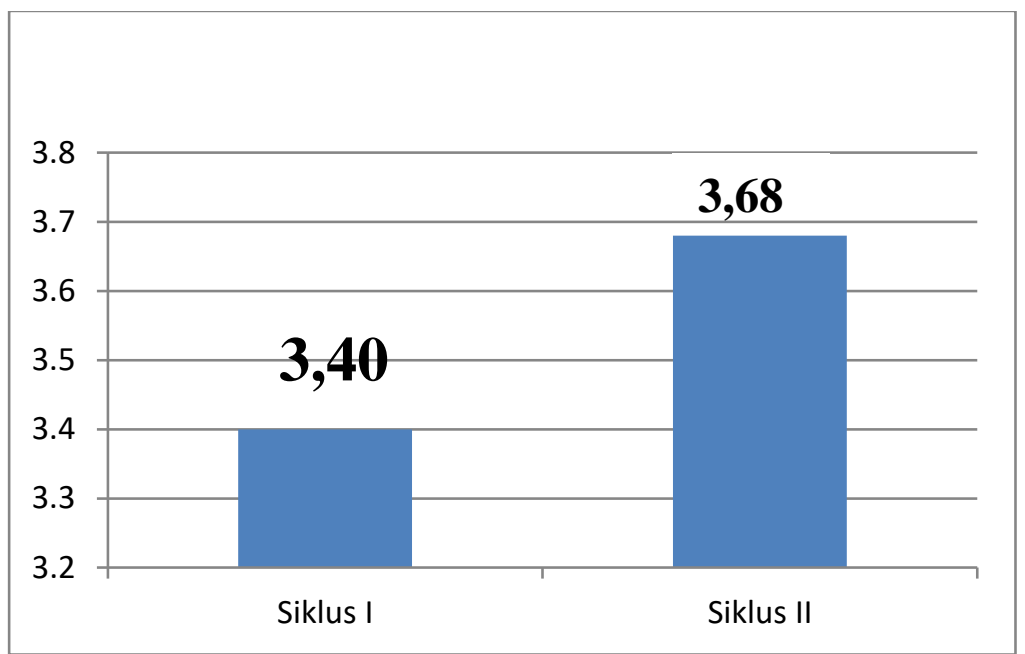
Siklus II

Gambar 3 Peningkatan Kemampuan Guru Dalam Mengelola Pembelajaran dari Siklus I ke

Gambar diatas menunjukkan kalau guru telah mampu meningkatkan Model Problem Based Learning pada materi pokok persamaan garis lurus di kelas VIII-1 SMP Negeri 4 Barumun dengan sangat baik sehingga dapat meningkatkan kemampuan berpikir kreatif siswa dalam belajar matematika dan juga meningkatkan aktivitas siswa dalam proses belajar.

\section{KESIMPULAN}

Berdasarkan tujuan penelitian, hasil penelitian dan pembahasan, maka penelitian yang dilaksanakan di Kelas VIII SMP Negeri 4 Barumun dapat disimpulkan sebagai berikut:

1. Model Problem Based Learning dapat meningkatkan kreativitas dan hasil belajar matematika siswa pada materi pokok persamaan garis lurus di kelas VIII SMP Negeri 4 Barumun tahun ajaran 20202021. Pada siklus I hasil tes kemampuan berpikir kreatif matematika siswa sebesar $46,1 \%$ dan pada siklus II 88,5\% hasil yang didapat pada siklus II menunjukkan bahwa sudah dapat terpenuhi kategori yang diharapkan yaitu $\geq 80 \%$. Berdasarkan hasil siklus I dan siklus II terdapat peningkatan persentase penilaian sebesar $42,4 \%$ dari 26 siswa yang mengikuti tes.

2. Penerapan Model Problem Based Learning dapat meningkatkan kadar aktivitas belajar siswa di kelas VIII SMP Negeri 4 Barumun tahun ajaran 2020-2021. Hal ini dapat dilihat dari hasil observasi aktivitas siswa siklus I 75,08\% dan siklus II 87,27\%. Berdasarkan hasil siklus I dan siklus II terdapat peningkatan sebesar 12,19\% dari 26 siswa. Hasil yang didapat pada siklus II menunjukkan bahwa sudah dapat terpenuhi kategori yang diharapkan yaitu $\geq 80 \%$.

3. Model Problem Based Learning dapat meningkatkan kemampuan guru mengelola pelajaran di kelas VIII SMP Negeri 4 Barumun tahun ajaran 2020-2021. Hal ini didukung dengan kategori yang didapat pada siklus I sebesar 3,40 dengan kategori "baik” dan siklus II meningkat menjadi 3,68.

\section{REFERENSI}

Abdurrahman, Mulyono. 2009. Pendidikan Bagi Anak Berkesulitan Belajar. Jakarta: Rineka Cipta. Arikunto, Suharsimi. 2013. Prosedur Penelitian Suatu Pendekatan Praktek. Jakarta: Rineka Cipta. Dewey. 2009. Pembelajaran Berbasis Masalah. Surabaya: Unesa University Press.

Dimiyati, dan Mudjiono, 2009, Belajar dan Pembelajaran. Jakarta: PT Rineka Cipta.

Gagne, 2009. Belajar Dan Pembelajaran. Jakarta: PT Rineka Cipta.

Gardner, Ardhana dkk. 2003. Manajemen Penelitian. Jakarta: PT Rineka Cipta.

Hamalik, 2011, Aktivitas - Aktivitas Belajar. Jakarta: PT Rineka Cipta.

Hamalik, Oemar, 2008, Proses Belajar Mengajar. Jakarta: Bumi Aksara.

Hamzah, 2009. Hakikat Belajar Matematika. Jakarta: PT Rineka Cipta. 
ISSN. 2621-9832

JURNAL MathEdu (Mathematic Education Journal) http://journal.ipts.ac.id/index.php/MathEdu Vol. 4 . No. 3 Mounth 2021

Ibrahim, M. dan Nur, M. 2000. Pembelajaran Berbasis Masalah. Surabaya: Unesa University Press.

Ismail. 2002. Pembelajaran Berbasis Masalah (Problem Based Instruction). Surabaya: University Press. Istarani. 2011. 58 Model Pembelajaran Inovatif. Medan: Media Persada.

Morgono, 2005 Metodologi Penelitian, Jakarta: Rineka Cipta

Mulyasa, Enco. 2009. Menjadi Guru Profesional. Bandung: PT Remaja Rosdakarya

Nuharini, Dewi, Tri Wahyuni. 2008. Matematika Konsep dan Aplikasinya Kelas VIII SMP/MTsN. Pusat Perbukuan, Jakarta.

Rusman, 2010. Model - Model Pembelajaran, Jakarta: Bumi Aksara.

Sanjaya, 2008. Pembelajaran Berbasis Masalah. Jakarta: Bumi Aksara.

Soedjadi, R. 2000. Kiat Pendidikan Matematika Di Indonesia: Konstitusi Keadaan Masa Kini Menuju Harapan Masa Depan. Jakarta: Dirjen Dikti Depdiknas. 